\title{
SUNFLOWER (Helianthus annuus L.) LANDRACES OF TURKEY - THEIR COLLECTION, CONSERVATION, AND MORPHOMETRIC CHARACTERIZATION
}

\author{
Tan, A.S. ${ }^{*}$ and Tan, A.
}

Ministry of Agriculture and Rural Affairs, General Directorate of Agricultural Research, Aegean Agricultural Research Institute, Plant Genetic Resources Department, PO Box: 9, Menemen, 35661 Izmir, Turkey

Received: April 10, 2010

Accepted: August 10, 2010

\section{SUMMARY}

Turkey is an important country for plant genetic resources. The conservation of plant genetic resources is important for the sustainable protection of genetic diversity. Because the new uniform and high-yielding varieties used in modern agriculture may cause the erosion of genetic diversity of local varieties or landraces, the collection and characterization of local germplasm becomes necessary. The sunflower (Helianthus annuus L.) is one of the important oilseed crops for Turkey. Sunflower landraces have significant diversity in Turkey as one of the micro-gene centers for sunflower. For this reason, sunflower landraces are collected within the framework of the National Industrial Plant Genetic Resources Project. These accessions are maintained long-term ex situ at the National Gene Bank and are characterized for better understanding of the eco-geographic variation of sunflower landraces throughout region and for assessing the sustainable utilization of these collections. The eco-geographical distribution of the landraces and agro-morphological variation of the sunflower collection of the National Gene Bank will be presented. The amount of diversity and the genetic resources of sunflower used as a source of morphological similarity or dissimilarity of sunflower genetic resources were analyzed. The sunflower accessions used in this study, which were collected from different sites in Turkey, were evaluated for morphological characters. Ecological differences affect the morphology of sunflower; thus, quantitative aspects of variation were evaluated using plants grown under the same conditions. Multivariate analysis was performed for diversity determination of sunflower and morphometric parameters were examined. The distribution areas of sunflower samples showed great diversity. The distinct groupings were determined in principal components and the results of the analysis exhibited a broad morphological variation model of sunflower landraces.

Key words: sunflower, Helianthus annuus L., ex situ conservation, diversity, agro-morphological variation, eco-geographical variation, multivariate analysis, Principle Component Analysis (PCA)

* Corresponding author: Phone: +902328461331/470; e-mail: a_s_tan@hotmail.com 


\section{INTRODUCTION}

Turkey is a unique country when it comes to plant diversity, as it is the center of origin and/or the center of diversity or micro-gene center for many crop species (Tan, 2009a; Karagoz et al., 2010). The sunflower, which originated in North America (Zeven and de Wet, 1982), is an important vegetable oil source both in Turkey and in the world at large. Although Turkey is not the origin of sunflower, the country is characterized by great morphological diversity in sunflower landraces because of natural selection during adaptation and farmers' selection for the desired characteristics of their preference for consumption (Tan, 2002).

The National Plant Genetic Resources and Plant Diversity Program of Turkey has been a highly organized endeavor since the 1960s that has involved the survey, collection, conservation (both ex situ and in situ, including on farm conservation of land races), characterization, and evaluation of existing genetic resources and genetic diversity (Tan, 2000; Tan, 2009a). Thus, the Industrial Crops Genetic Resources Program as part of the above National Program collects various industrial crops landraces and wild species for the purposes of long-term conservation at the National Gene Bank of the Aegean Agricultural Research Institute (AARI) and carries out the characterization of said collections at the gene bank (Tan et al., 2009).

While many environmental factors affect the loss of wild species, the threat factors to landraces/local varieties are mainly the result of the replacement of landraces with modern varieties and changes in the agricultural farming system.

Highly variable domesticated crops as well as landraces with unique characteristics are still grown by farmers in Turkey.

The factors prompting the farmers (even modern ones) to keep their landraces or traditional crops (Tan, 2002) are as follows:

1. Fragmentation of land holdings allows farmers to manage several fields and to keep local landraces,

2. Marginal agronomic conditions, especially steep slopes and heterogeneous soils of mountain agriculture, make local landraces competitive with improved cultivars, at least in part of the farming system,

3. Economic isolation creates market imperfection and lessens to the competitive advantages of improved cultivars,

4. Cultural identity, traditions, and preference of diversity lead farmers to keep local landraces.

From different provinces and different sources (such as fields, farmer storage, threshing places, and local village markets), 236 confectionary- and oilseed-type sunflower landraces have so far been collected and stored long-term at the National Gene Bank. Figure 1 shows the collection sites of these sunflower landraces.

Genetic diversity plays an important role in plant breeding. Hybrids of parental lines with diverse origin generally display a greater level of heterosis than those 
between closely related parents (Tan, 1993; Tan, 2005). Thus, the characterization of the existing collection is essential for the breeders. Characterization of genetic resources collections of confectionary and oilseed sunflowers is critical in assessing collection diversity and enhancing utilization. The existing sunflower collections have been started to be characterized and evaluated for utilization at the breeding program at AARI. The Ege2000 open-pollinated oilseed variety has been developed and registered, and oilseed and confectionary types of germplasm have been developed and varieties have been proposed for registration (Tan, 2009b).

\section{MATERIAL AND METHOD}

Sunflower landraces have been collected from different locations in Turkey within the framework of the National Industrial Plant Genetic Resources Project of the National Plant Genetic Resources and Plant Diversity Program and are conserved at the National Gene Bank. Thirty accessions (landraces from the West of Turkey) from the sunflower collection of the National Gene Bank were used in this study for characterization purposes. The rest of the accessions will continue to be characterized.

The accessions were grown in two rows with fifty plants. Twenty randomly selected plants were observed from each sample (accession). Twenty six morphological characters (plant, head/flower and seed characteristics) were observed (Table 1). Days to flowering and days to physiological maturity were also recorded.

Table 1: The observed morphological characters (IBPGR, 1985)

\begin{tabular}{ccc}
\hline Plant characteristics & Head/flower characteristics & Seed characteristics \\
\hline Plant vigor & Number of heads & Husk percentage $(\%)$ \\
Plant height $(\mathrm{cm})$ & Poed length $(\mathrm{mm})$ \\
Stem width $(\mathrm{cm})$ & External pertal color & Seed shape \\
Stem color & Head flower color & 1000-seed weight $(\mathrm{g})$ \\
Pubescence at stem & Head size $(\mathrm{cm})$ & \\
Type of branching & Head angle & \\
Number of leaves & Head shape & \\
Leaf color & Head weight $(\mathrm{kg})$ & \\
Pubescence on leaf & & \\
Leaf wing & & \\
Leaf edge & & \\
Leaf shape & & \\
Leaf width $(\mathrm{cm})$ & & \\
Leaf length $(\mathrm{cm})$ & & \\
\hline
\end{tabular}

The collection and passport data and storage and characterization data are stored in the National Plant Genetic Resources Database (Tan and Tan, 1998a; Tan and Tan, 1998b). 
Statistical analysis and Multivariate Analysis (Principal Component AnalysisPCA) were performed to determine the variation among the accessions (Sneat and Sokal, 1973; Clifford and Stephenson, 1975). The statistical values of quantitative characters were calculated (Steel and Torrie, 1980).

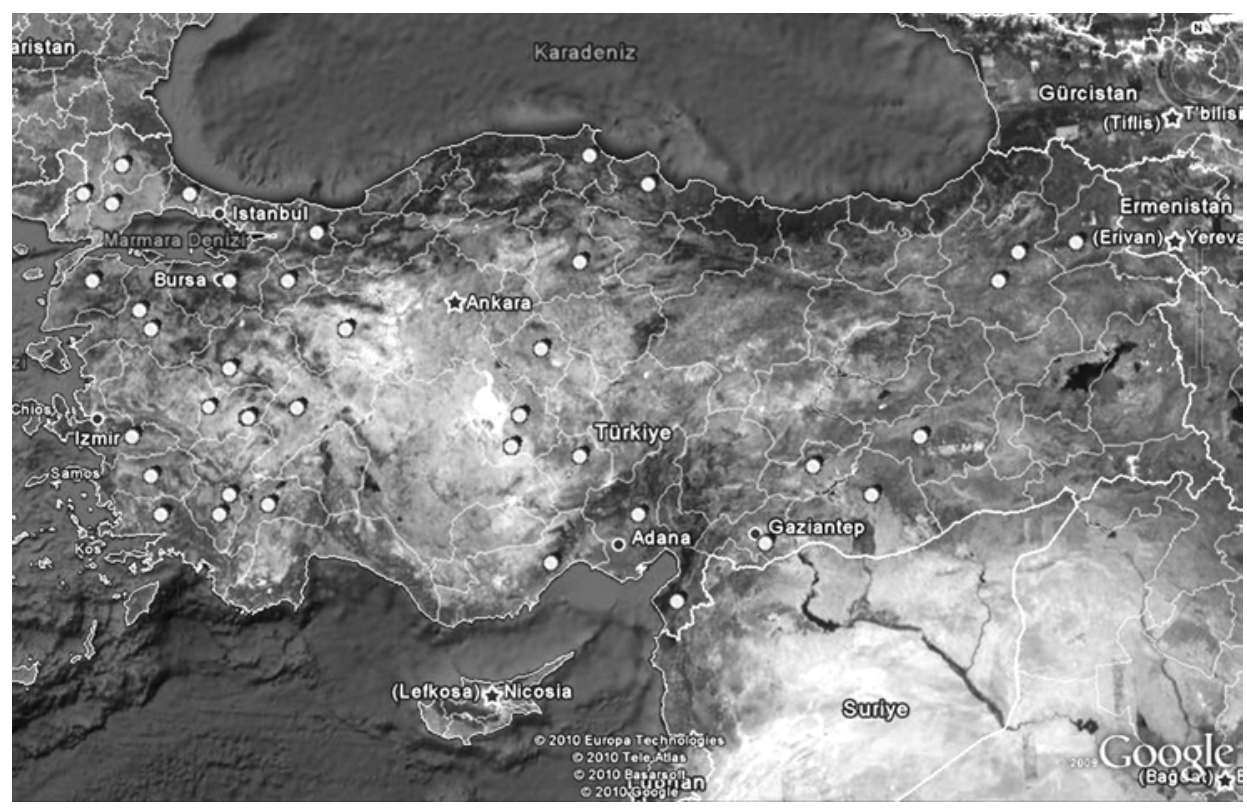

Figure 1: Sunflower landraces collection sites.

\section{RESULT AND DISCUSSION}

\section{Morphological characters}

The morphological variation of the observed characters was found to be very high for some characters. There was no variation in pollen fertility. All accessions released fertile pollen and plants were mostly vigorous. Stems were mostly pubescent and leaf shape was observed mostly as triangular but cordate and rounded leaves were also observed and recorded. Head angle vas very variable at maturity, and all types were observed $\left(0^{\circ}, 45^{\circ}, 90^{\circ}, 135^{\circ}, 180^{\circ}\right.$ and $\left.225^{\circ}\right)$. Head shapes were also presented as concave, flat, convex, misshapen. Type of branching was another variable character, but mostly basal branching and top branching were observed. Full branching with central head was also observed in some plants of some acces- 
sions. The variation of quantitative characters is shown in Table $2 a$ and Table $2 b$ with minimum and maximum values and variances of the characters.

Table 2a: The variation of the quantitative characters

\begin{tabular}{lccccc}
\hline Statistical values & $\begin{array}{c}\text { Days to } \\
\text { flowering }\end{array}$ & $\begin{array}{c}\text { Days to } \\
\text { maturity }\end{array}$ & $\begin{array}{c}\text { Plant height } \\
(\mathrm{cm})\end{array}$ & $\begin{array}{c}\text { Head size } \\
(\mathrm{cm})\end{array}$ & $\begin{array}{c}\text { 1000-seed } \\
\text { weight }(\mathrm{g})\end{array}$ \\
\hline Min. & 52.00 & 108.00 & 157.00 & 16.40 & 78.40 \\
Max. & 70.00 & 115.00 & 238.80 & 27.00 & 109.00 \\
Mean & 54.93 & 110.29 & 174.36 & 20.04 & 92.55 \\
$S^{2}$ (Variance) & 16.8095 & 3.1005 & 302.6380 & 4.4914 & 81.1013 \\
S (Standard error) & 4.10 & 1.76 & 17.40 & 2.12 & 9.01 \\
SE $\bar{X}$ (Standard error of the mean) & 0.7748 & 0.3328 & 3.2876 & 0.4005 & 1.7019 \\
CV (\%) & 7.46 & 1.60 & 9.98 & 10.58 & 9.73 \\
\hline
\end{tabular}

Table $2 \mathrm{~b}$ : The variation of the quantitative characters

\begin{tabular}{lcccccc}
\hline Statistical values & $\begin{array}{c}\text { Husk } \\
\text { percentage } \\
(\%)\end{array}$ & $\begin{array}{c}\text { Seed } \\
\text { length } \\
(\mathrm{mm})\end{array}$ & $\begin{array}{c}\text { Number } \\
\text { of leaves }\end{array}$ & $\begin{array}{c}\text { Leaf } \\
\text { width } \\
(\mathrm{cm})\end{array}$ & $\begin{array}{c}\text { Leaf } \\
\text { length } \\
(\mathrm{cm})\end{array}$ & $\begin{array}{c}\text { Stem } \\
\text { width } \\
(\mathrm{cm})\end{array}$ \\
\hline Min. & 20.95 & 10.66 & 26.00 & 16.60 & 18.00 & 1.70 \\
Max. & 40.73 & 14.92 & 43.00 & 29.00 & 24.60 & 3.40 \\
Mean & 25.87 & 11.57 & 30.43 & 21.48 & 20.60 & 2.23 \\
$\mathrm{~S}^{2}$ (Variance) & 19.2756 & 0.6667 & 13.0688 & 5.9906 & 3.1807 & 0.1015 \\
S (Standard error) & 4.39 & 0.82 & 3.62 & 2.45 & 1.78 & 0.32 \\
SE $\bar{x}$ (Standard error of the mean) & 0.8297 & 0.1543 & 0.6832 & 0.4625 & 0.3370 & 0.0602 \\
CV (\%) & 16.97 & 7.06 & 11.88 & 11.40 & 8.66 & 14.27 \\
\hline
\end{tabular}

\section{Principal component analysis}

Principal component analysis (PCA) showed that the first six principal components (PRINs) accounted for $86.417 \%$ of the total variation. Detailed results of principal component analysis with latent roots (Eigen values), percentage variance and cumulative variance values are given in Table 3 .

Table 3: Result of principal component analysis

\begin{tabular}{lccc}
\hline PRIN \# & $\begin{array}{c}\text { Latent roots } \\
\text { (Eigen values) }\end{array}$ & $\begin{array}{c}\text { Percentage } \\
\text { variance }\end{array}$ & $\begin{array}{c}\text { Cumulative } \\
\text { variance }\end{array}$ \\
\hline PRIN 1 & 7.570 & 36.046 & 36.046 \\
PRIN 2 & 4.732 & 22.531 & 58.577 \\
PRIN 3 & 2.342 & 11.150 & 69.727 \\
PRIN 4 & 1.330 & 6.333 & 76.061 \\
PRIN 5 & 1.155 & 5.499 & 81.560 \\
PRIN 6 & 1.020 & 4.857 & 86.417 \\
PRIN 7 & 0.810 & 3.857 & 90.273 \\
PRIN 8 & 0.626 & 2.981 & 93.254 \\
PRIN 9 & 0.458 & 2.182 & 95.436 \\
PRIN10 & 0.327 & 1.555 & 96.991 \\
\hline
\end{tabular}


The first two principal components (PRN1 and PRN2) accounted for 58.577\% of total variance. External petal color, pollen fertility, head angle, head flower color, and pubescence of leaves were effective variables on PRN1, and plant height $(\mathrm{cm})$, seed length $(\mathrm{mm})$, leaf width $(\mathrm{cm})$, leaf length $(\mathrm{cm})$, and stem width $(\mathrm{cm})$ were effective variables on PRN2 to form the groups and the scattering of the accessions. Only one group was formed that consisted of the oil types and the confectionary samples from Balikesir, Tekirdag, Bursa, Çanakkale (Biga), Çanakkale (Ayvacik) were separate from this group (Figure 2).

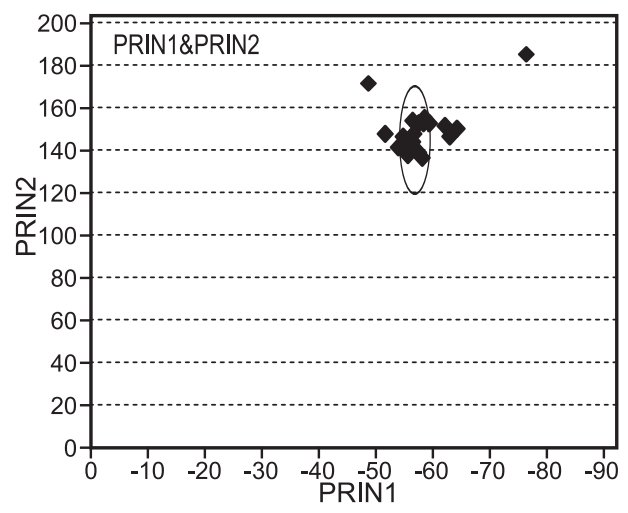

Figure 2: Distributions and grouping of the samples on PRIN1 and PRIN2.

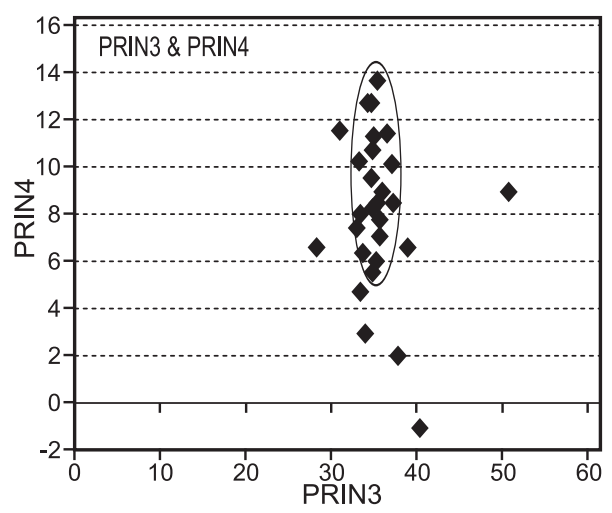

Figure 3: Distributions and grouping of the samples on PRIN3 and PRIN4.

The second pair of principal components (PRN3 and PRN4) accounted for $76.061 \%$ of total variance. External petal color, pollen fertility, head angle, and husk percentage were effective characters on PRN3 and 1000-seed weight (g) and pubescence of stem were effective characters on PRN4. In this scatter one group was formed that consisted of the oil types and all the confectionary types and some oil types with large seeds were outside this group. Those samples were from the Balikesir, Tekirdag, Bursa, Çanakkale (Biga), Çanakkale (Ayvacik), Istanbul (Silivri), and Balikesir (Gönen) provinces (Figure 3).

The third pair of principal components (PRN5 and PRN6), accounting for $86.417 \%$ of total variance, was formed by the effect of the effective variables head shape on PRN5 and type of branching and husk percentage on PRN6. In this scatter one group was observed, as in the other principal component pairs. The pattern was almost the same and the confectionary types were outside the group. Those accessions were collected from the Balikesir, Tekirdag, Bursa, Çanakkale (Biga), Çanakkale (Ayvacik), Istanbul (Silivri), Edirne, Kirklareli, and Sakarya provinces (Figure 4).

The results indicated that the sunflower landraces (especially the confectionary types) were very variable for morphological characters. The separation and grouping of the scattered accessions in the principal components mostly depended on the type of accession (oilseed or confectionary). Although most of the confectionary 
types were scattered outside the groups in all principal components, some oil types were also outside the groups depending on some variable characters. The variation was also observed not only among accessions but also within them.

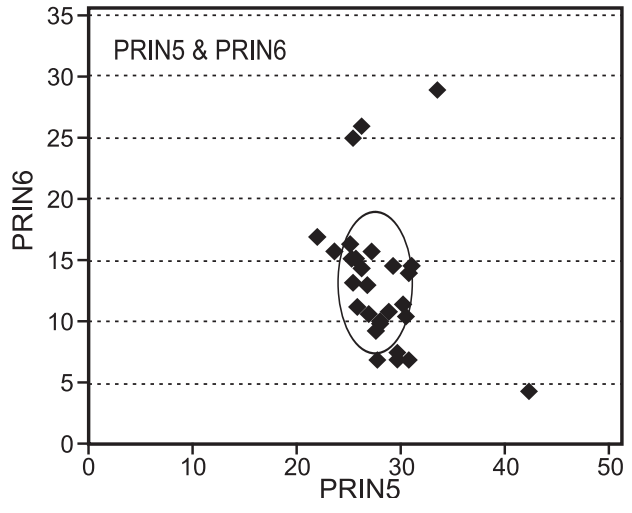

Figure 4: Distributions and grouping of the samples on PRIN5 and PRIN6.

Although the morphological-based group showed some locality separation by germplasm origin, in general the origin did not correspond closely with the grouping pattern. The variation of the landraces among and within the provinces (and even in the villages) on some characters brings up the consideration of adaptation to different ecological conditions and also the different preferences of the farmers selection. Some degree of similarity between some accessions collected from different localities of different provinces may result in the informal seed exchange mechanism among the farmers.

Landraces exhibit varying degrees of morphological and genetic integrity and may change with time, but they are recognized by farmers on the basis of a number of morphological and agronomic criteria. Genetic resources scientists and plant breeders, however, may look to preserve particular crops and crop varieties as a means of ensuring that the maximum possible range of plant genetic resources is available today and in the future. Therefore, the landraces, before they are replaced with modern varieties, should be collected, conserved and evaluated as source of breeding for the broad base. For this purpose, the existing landraces still grown by the farmers are collected and started to be characterized morphologically and used in breeding programs on oilseed and confectionary sunflowers. The next step is the completion of the characterization and full evaluation of the entire national sunflower collection conserved at the National Gene Bank.

\section{REFERENCES}

Clifford, H.T. and Stephenson, W., 1975. An introduction to numerical classification. Academic Press. New York.

IBPGR. 1985. Sunflower descriptors. International Board for Plant Genetic Resources (IBPGR). Rome, Italy.

Karagoz, A., Zencirci, N., Tan, A., Taskin, T., Köksel, H., Surek, M., Toker, C. and Ozbek, K., 2010. Bitki Genetik Kaynaklarinin Korunmasi ve Kullanimi (Conservation and utilization of plant genetic resources). Türkiye Ziraat Mühendisligi VII. Teknik Kongresi. 11-15 Ocak 2010, Ankara. Bildiriler Kitabi 1, 155-177.

Sneath, P.H.A. and Sokal, R.R., 1973. Numerical taxonomy. The principles and practice of numerical classification. Freeman, San Fransisco. 
Tan, A., 2000. Biodiversity conservation. Ex situ and in situ conservation: a case in Turkey. In: Watanabe K. and A. Komamine (eds.). Chalenge of Plant and Agricultural Sciences to the crisis of biosphere on the Earth in the $21^{\text {st }}$ century. Eurekah, Texas.

Tan, A., 2002. Türkiye (Geçit Bölgesi) Genetik Çeşitliliginin In Situ (Çiftçi Şartlarinda) Muhafaza Olanaklarinin Araştirilmasi (In-situ On-farm Conservation of Landraces grown in NorthWestern Transitional Zone of Turkey). Sonuc Raporu. (Final Report). TUBITAK-TOGTAG-2347. TUBITAK. Ankara.

Tan, A., 2009a. State of plant genetic resources for food and agriculture in turkey. Second national report of turkey on conservation and sustainable utilisation of plant genetic resources for food and agriculture. ftp://ftp.fao.org/ag/agp/countryreports/TurkeyFINALCR.pdf.

Tan, A.S., 2009b. Ege Bölgesi Ayçiçegi Araştirmalari Projesi. 2009 Yili Gelişme Raporu (Sunflower Researches for Aegean Region of Turkey. Annual Report of 2009). Ege Tarimsal Arastirma Enstitüsu) Aegean Agriculture Research Institute). Menemen-Izmir, Turkey.

Tan, A.S., 1993. Ayçiçeginde (Helianthus annuus $\mathrm{L}$.$) melez varyete \left(\mathrm{F}_{1}\right)$ islahinda kendilenmiş hatlarin çoklu dizi (line $\times$ tester) analiz yöntemine göre kombinasyon yeteneklerinin saptanmasi üzerine araştirmalar. Doktora tezi. E.Ü. Zir. Fak. Fen Bil. Ens. Tarla Bit. Ana Bil. Dali. Bornova - Izmir.

Tan, A.S., 2005. Heterosis. Bitki Islahinda Istatistik Genetik Metotlar. Ege Tar. Ara. Enst. No: 121. Menemen, Izmir pp. 33-71.

Tan, A.S., Tan, A., Aykas, L., Elmas, S., Yildizdal, I. and Peksuslu, A., 2009. Endüstri Bitkileri Genetik Kaynaklari Projesi. 2009 Yili Geliime Raporu. (Industrial crops resources research project. Annual Report, 2009). Ege Tarimsal Arastirma Enstitüsu) Aegean Agriculture Research Institute). Menemen- Izmir,Turkey.

Tan, A. and Tan, A.S., 1998a. Database management systems for conservation of genetic diversity in Turkey. In: Zencirci, N., Kaya, Z., Anikster, Y., Adams, W.T., (Eds.). The Proceeding of International Symposium on In situ Conservation of Plant Genetic Diversity. 4-8 November, 1996. Antalya, Turkey.

Tan, A., and Tan, A.S. 1998b. Data collecting and analysis for in situ, on farm, conservation. In: Jarvis D.I. and Hodghin, T. (Eds.) Stregnghthen the scientific basis of in situ conservation of agricultural biodiversity on-farm. Options for data collecting and analysis. Proceedings of a Workshop to Develop Tools and Procedures for In Situ Conservation On-farm, 25-29 August 1997, Rome, Italy, IPGRI.

Steel, R.G.D., and Torrie, J.H., 1980. Principles and procedures of statistics. A biometrical approach. Mc Grow-Hill Book Co. New York.

Zeven, A.C, de Wet, J.M.J., 1982. Dictionary of cultivated plants and their regions of diversity. Pudoc, Wageningen, the Netherlands. pp. 1-200. 